\section{SCS122 Miura - New Rice Cultivar}

\section{Rubens Marschalek ${ }^{1}$, Jose Alberto Noldin ${ }^{1}$, Ester Wickert ${ }^{1}$, Klaus Konrad Scheuermann ${ }^{1}$, Moacir Antonio Schiocchet ${ }^{1}$, Domingos Savio Eberhardt ${ }^{1}$, Ronaldir Knoblauch ${ }^{1}$, Eduardo Hickel $^{1}$, Gabriela Neves Martins ${ }^{1}$, Juliana Vieira Raimondi ${ }^{2}$ and Alexander de Andrade ${ }^{1^{*}}$}

\begin{abstract}
The rice cultivar SCS122 Miura has modern architecture, lodging resistance, late maturity cycle, moderate resistance to blast, high yield potential, long grains and adequate cooking quality. Industrial tests have demonstrated that the grains are suitable for parboiled rice. SCS122 Miura is recommended for all rice-producer regions of the state of Santa Catarina, Brazil.
\end{abstract}

Key words: Oryza sativa, breeding, variety.

\section{INTRODUCTION}

The state of Santa Catarina is the second largest irrigated rice producer in Brazil, with a cultivated area of 147,400 ha, and an annual production of 1.052 .300 tons of paddy rice (CONAB 2016). The activity provides high generation of foreign exchange and has a great socio-economic role in the state. The development of cultivars adapted to different soil and climatic regions is fundamental to maintain Santa Catarina rice industry competitive, and consequently the local farmers. SCS122 Miura is a new irrigated cultivar developed by Epagri Rice Breeding Program, and it is recommended for all rice-producer regions of Santa Catarina. Industrial tests carried out with this cultivar showed that the grains are suitable for parboiled rice.

\section{PEDIGREE AND BREEDING METHOD}

SCS122 Miura was derived from a single cross between the line PR122 (IAPAR) and SCSBRS Tio Taka (Rangel et al. 2007), in 2003. In the following year (2004), $F_{1}$ plants were crossed with Epagri's inbreed line SC 354, which is a multispike line. The seeds obtained were sown to form the $F_{2}$ population. $F_{2}$ generation plants showed genetic variability, as expected. The selection process started with phenotypic traits of interest, such as plant type, height, yield, grain type, number of grain per panicle, and panicle type. Plants individual selection formed $\mathrm{F}_{3}$ families, which, in turn, originated the $\mathrm{F}_{4}$ generation. Agronomical traits, such as yield, were evaluated, starting with $F_{3}$ families. Seeds of the plants selected in the $\mathrm{F}_{4}$ generation formed the lines of the "preliminary trial", and of the $F_{5}$ generation. During these stages, populations were grown following Epagri's technological recommendations for rice (Eberhardt and Schiocchet 2015). At every stage, the occurrence of blast (Pyricularia oryzae) and other diseases were carefully registered, in order to select genotypes with disease tolerance. In
Crop Breeding and Applied Biotechnology 17: 292-294, 2017 Brazilian Society of Plant Breeding. Printed in Brazil http://dx.doi.org/10.1590/198470332017v17n3c44 \title{
(n)
}


the $F_{6}$ generation (2011/2012), the new inbreed line was named as SC 681, and was again evaluated for yield potential, lodging resistance, plant height, tolerance to iron toxicity, blast resistance, and grain quality (Marschalek et al. 2017). Moreover, the line SC 681 was included in the trials to evaluate the Value for Cultivation and Use (VCU), carried out for two seasons (2012 and 2013) in Itajaí, Pouso Redondo and Massaranduba. Statistical analysis was carried out using the Scott-Knott test at 5\%. The line SC 681 showed uniformity, good milling yield, and good agronomic traits, being suitable for milled and parboiled rice. SC 681 presented lodging resistance, moderate resistance to blast, and susceptibility to rice leaf scald. Based on the results of the VCU trials, the line SC 681 was released in 2017, as SCS122 Miura. The cultivar's name was a tribute to the phytopathologist Lucas Miura, who spent many years as a dedicated scientist at the Experiment Station of Itajaí/Epagri.

\section{TRAITS PERFORMANCE}

The agronomic traits of the cultivar SCS122 Miura are listed in Table 1. These evaluations were based on the Handbook of Research Methods in Rice (Embrapa 1977). SCS122 Miura has modern architecture, with late maturity life cycle (137-144 days), high tillering capacity, and erect and hairy leaves. The cultivar is resistant to lodging, which is considered as essential trait for the pre-germinated system, the most commonly used in Santa Catarina. The cultivar also presents intermediate shattering and intermediate resistance to iron toxicity and blast disease. SCS122 Miura presented mean yield of $9.388 \mathrm{~kg} \mathrm{ha}^{-1}$ in VCU trials (Itajaí, Pouso Redondo and Massaranduba counties), which is higher than those of the controls (Table 2). SCS122 Miura also has good processing performance for parboiling rice. Therefore, as a result of the good agronomic traits, and due to acceptable industrial and sensory performance, this cultivar is recommended to rice-producers in all rice production areas in the state of Santa Catarina.

SCS122 Miura has long and translucent grains, acceptable cooking qualities, and milling yield of $67.5 \%$ (Table 3 ). The evaluations for the industrial grain traits showed that the cultivar is suitable for the parboiling process, and both milled and parboiled grains present glassy appearance.

Table 1. Agronomic traits of cultivar SCS122 Miura in VCU trials (Itajaí, Pouso Redondo and Massaranduba), in 2012/13 and $2013 / 14$

\begin{tabular}{ll}
\hline Plant trait & Description \\
\hline Leaf color & Green \\
Leaf pubescence & Medium \\
Flag leaf angle & Upright \\
Tillering & High \\
Cycle to maturity & $137-144$ days \\
Plant height & $74.6 \mathrm{~cm}$ \\
Lodging & Resistant \\
Disease resistance: & \\
Leaf blast & Moderately resistant \\
Panicle blast & Moderately resistant \\
Brown spot & Moderately resistant \\
Rice leaf scald & Susceptible \\
Iron toxicity tolerance & Susceptible \\
Glumella color & Golden \\
Apex color at maturity & White \\
Awns & Absent \\
Shattering & Intermediate \\
\hline
\end{tabular}

Table 2. Mean grain yield ( $\mathrm{kg} \mathrm{ha}^{-1}$ ) of SCS122 Miura, Epagri 109, and SCS116 Satoru, in VCU trials (Itajaí, Pouso Redondo and Massaranduba), in 2012/2013 and 2013/2014 seasons

\begin{tabular}{|c|c|c|c|c|c|c|c|}
\hline \multirow[t]{3}{*}{ Cultivars } & \multicolumn{2}{|l|}{ Itajaí } & \multicolumn{2}{|c|}{ Pouso Redondo } & \multicolumn{2}{|c|}{ Massaranduba } & \multirow[t]{2}{*}{ Means } \\
\hline & 2012 & 2013 & 2012 & 2013 & 2012 & 2013 & \\
\hline & & & $\mathrm{kg} \mathrm{ha}^{-1}$ & & & & \\
\hline SCS122 Miura & 9.900 & 8.196 & 11.100 & 9.984 & 9.900 & 7.249 & $9.388 \mathrm{a}$ \\
\hline Epagri 109 & 8.800 & 5.383 & 9.200 & 8.274 & 8.900 & 7.121 & $7.946 b$ \\
\hline SCS116 Satoru & 9.600 & 6.962 & 7.600 & 9.381 & 8.900 & 6.207 & $8.108 \mathrm{~b}$ \\
\hline
\end{tabular}

Means followed by the same letter are not significantly different by the Scott-Knott's test at $5 \%$ probability.

Table 3. Physical characteristics of grains of SCS122 Miura rice cultivar

\begin{tabular}{lcccccccccc}
\hline \multirow{2}{*}{ Cultivar } & \multicolumn{4}{c}{ Traits* } & \multicolumn{4}{c}{ Grain size $(\mathrm{mm}) * *$} \\
\cline { 2 - 10 } & Total & AC & GT & WB & L & W & T & L/W & Class \\
\hline SCS122 Miura & $67.5 \%$ & I & H & 2 & 7.23 & 2.08 & 1.72 & 3.48 & Long-thin \\
\hline
\end{tabular}

Total: Total percentage of grains milled; AC: Percentage of amylose content; GT: Gelatinization temperature (I: intermediate, H: high); WB: White belly grade; L: Grain length; W: Grain width; T: Thickness; and L/W: Length width ratio. *Embrapa/CNPAF, ** 2,129 grains analyzed by the Image Rice Grain Scanner (Marschalek et al. 2017). 
Cooking tests confirmed the good quality of the cultivar, since grains remain loose with soft texture, good aroma, and normal taste. Sensory evaluation of parboiled rice resulted in good consumer acceptance.

\section{FOUNDATION SEED PRODUCTION}

SCS122 Miura is protected by the Ministério da Agricultura, Pecuária e Abastecimento (Ministry of Agriculture, Livestock and Supply) under the registration number 36176. Genetic seed stock is kept at the Experiment Station of Itajaí/Epagri, located at Rodovia Antônio Heil, n.6800, Itaipava, CEP 88318-112, Itajaí, SC, Brazil. Certified seeds of the cultivar SCS122 Miura are produced by the Santa Catarina Rice Seed Producers Association (Acapsa).

\section{ACKNOWLEDGEMENTS}

This technology was financially supported by the National Council for Scientific and Technological Development (CNPq), Santa Catarina Research Foundation (Fapesc), and by the Brazilian Innovation Agency (Finep). The authors are grateful to the Santa Catarina Rice Seed Producers Association (Acapsa), to the Union of Industries of Rice in the State of Santa Catarina (Sindarroz-SC), and to the Brazilian Agricultural Research Corporation (Embrapa Rice \& Beans) for the sensorial and chemical analysis of grains.

\section{REFERENCES}

CONAB - Companhia Nacional de Abastecimento (2016) Acompanhamento da safra brasileira de grãos 2015/2016 - segundo levantamento. Conab, Brasilia, 156p. Available at < http://www.conab.br >. Accessed on December 05, 2016.

Embrapa (1977) Manual de métodos de pesquisa de arroz: $\mathbf{1}^{\mathrm{a}}$ aproximação. Embrapa Arroz e Feijão, Goiânia, 106p.

Eberhardt DS and Schiocchet MA (2015) Recomendações para a produção de arroz irrigado em Santa Catarina (Sistema pré-germinado). Epagri, Florianópolis, 92p.
Marschalek R, Vieira J, Schiocchet MA, Ishiy T and Bacha RE (2008) Melhoramento genético de arroz irrigado em Santa Catarina. Agropecuária Catarinense 21: 54-56.

Marschalek R, Silva MC, Santos SB, Manke JR, Bieging C, Porto G, Wickert E and Andrade A (2017) Image - Rice Grain Scanner: a threedimensional fully automated assessment of grain size and quality traits. Crop Breeding and Applied Biotechnology 17: 89-97.

Rangel PHN, Brondani C, Morais OPDE, Schiocchet MA, Borba TCO, Rangel PN, Brondani RPV, Yokoyama S, Bacha RE and Ishiy T (2007) Establishment of the irrigated rice cultivar SCSBRS Tio Taka by recurrent selection. Crop Breeding and Applied Biotechnology 7:103-110. 